\title{
Crisis Response via Dynamic Capabilities: A Necessity in NPOs' Capability Building
}

\author{
Insights from a Study in the European Refugee Aid
}

\author{
Katharina Kaltenbrunner $^{1}$ - Astrid Reichel ${ }^{2}$
}

Published online: 16 January 2018

(C) The Author(s) 2018. This article is an open access publication

\begin{abstract}
Dynamic capability research increasingly seeks to identify mechanisms founding dynamic capabilities because this microfoundation provides options for influencing the application of dynamic capabilities. Dynamic capabilities in turn support organizations to achieve continuous organizational change. We pursue deeper insight into the microfounding mechanisms of dynamic capabilities with regard to management-related variables. Survey data from hot spots of refugee crisis 2016 all across Austria allow us to examine how managerial mechanisms on microlevel and dynamic capabilities on macro-level are linked and particularly how managers can influence the application of dynamic capabilities. Data evaluation is based on mediation analysis. Study reveals that participative leadership fosters dynamic capabilities of NPOs active in refugee aid. Further, we provide evidence that the manager's perception, how self-determined he/she is and how impactful his/her actions are, enhances the application of dynamic capabilities.
\end{abstract}

Katharina Kaltenbrunner

katharina.kaltenbrunner@sbg.ac.at

Astrid Reichel

astrid.reichel@sbg.ac.at

1 Strategic Management and Organization, Paris Lodron University of Salzburg, Salzburg, Austria

2 Human Resource Management Group, Paris Lodron University of Salzburg, Salzburg, Austria

\section{Introduction}

Times of crisis and political upheavals reinforce NPOs' roles as advocates, service providers as well as place for social engagement and thus highlights NPOs' position as central hub between government, affected individuals and other civil society actors (Simsa and Zimmer 2014; Meyer et al. 2010; Anheier 2005). The significance of NPOs' as civil society actor became especially evident in the 'refugee crisis' of 2015/16. Due to Austria's geographic position and particularly its closeness to the 'welcome-nation' Germany, the country with a population of 8.7 million was confronted with more than one million refugees from Syria, Iraq and Afghanistan mostly transiting, but with over 100.000 also seeking asylum in Austria. ${ }^{1}$ This huge amount of refugees by far exceeded Austria's governmental structures and its capacity in crisis and emergency management $(\mathrm{CEM})^{2}$ (Roth 2017, 6; Maduz and Roth 2017; 2 ff.; Gratz 2016, 167 ff.). Particularly, Austria lacked an appropriate national CEM strategy, which regulates CEM across federal states. Hence, coordination of refugee aid across federal states was mainly informal (Gratz 2016, 91; Roth 2017, 7).

\footnotetext{
$\overline{1}$ There were about 900.000 arrivals of refugees (Roth 2017,6) and about 88.000 applications for asylum in 2015 (BMI Austria 2017a) and 135.000 arrivals of refugees during the first half of 2016 (Die Presse 2016) and 42.073 applications for asylum in 2016 (BMI Austria 2017b).

2 This may be rooted in the nature of the Austrian CEM, which is very military. It is based on centralized decision-making processes, strict command and control structures including clearly defined processes and standards. It is definitely not characterized by decentralized decisions and flexible and open governance/coordination structures allowing improvisation (Gratz, 2016, 92 c.f. Dynes, 1993), which would have been necessary, though, to handle the complexity and dynamics of the refugee crisis (Gratz, 2016, 92).
} 
NPOs, particularly established rescue and aid organizations, strived to close this gap together with other civil society actors, such as grass-roots initiatives, self-organized volunteers (Simsa 2017, 79) and for-profit organizations, mainly infrastructure organizations and security firms (Gratz 2016, 142 ff.). In this context, NPOs were active in strategic political as well as in operative CEM. They substituted governmental deficiencies concerning strategic leadership and coordination of refugee aid as well as operative CEM issues, such as public security at national boarders (registration, transport, etc.) and primary care for refugees and asylum seekers (food supply, medication, etc.). NPOs also compensated privatized public duties, such as providing accommodation for asylum seekers (Maduz and Roth 2017; Frühwirth and Lachmayer 2015).

In sum, the 'Austrian refugee crisis' centered on coping with transit refugees and it was handled by a multiplicity of actors (Simsa 2017; Roth 2017; Maier and Ortner 2017). NPOs and other civil society actors predominantly fulfilled tasks, which exceeded governmental capacity in CEM or tasks, which have not been legally determined and were left to informality (Roth 2017, 7; Gratz 2016, 91).

NPOs success in coping with the refugee crisis, particularly its capacity to handle the dynamics during these times, was substantially based on their experiences in international disaster relief and on their huge pool of human resources, especially volunteers (Simsa 2017; Gratz 2016). In addition to resources, NPOs displayed organizational capabilities, which were substantial to handle refuge crisis. NPOs were able to provide time-critical status reports including the identification of opportunities and threats, even though there was a lack of official communication structures. They managed to set up coordination and cooperation structures between diverse actors, and they were able to combine different logics such as spontaneous activism of volunteers and planning approach of rescue units in decision-making processes (Gratz 2016, 29 u. 63 f.). NPOs also succeeded in (re-)combining resource pools innovatively to set up critical infrastructure (Maduz and Roth 2017).

Being able to cope successfully with the situation described strongly suggests the presence of specific organizational capabilities-dynamic capabilities (DCs). This is because DCs are, firstly, capabilities which enable an organization to sense changes - opportunities and threatsand define possible resource actions (Teece 2007, 2014). Secondly, DCs help an organization seizing opportunities by selecting the appropriate resource actions and then implementing these decisions. Thirdly, DCs transform or rather align resources to the environmental dynamics (e.g., clients', government's, other partners' needs) (Teece 2014; Jantunen et al. 2012). In short, DCs support organizations to adapt to changing conditions by contributing to an environment-organization fit and hence support organizations to compete in dynamic environments (Di Stefano et al. 2014, 315). Correspondingly, DCs are prevalently related to positive performance effects (Teece et al. 1997, Teece 2007; Wang and Ahmed 2007).

While there is (some) research regarding performance effects of DCs in NPOs (Piening 2013; Kaltenbrunner 2018), it remains largely unclear, which intra-organizational mechanisms foster the application of DCs (Pavlou and El Sawy 2011; Sprafke et al. 2013). Particularly, the link between organizations as agents on a macro-level and managers as agents on a microlevel needs to be explored in more detail (Di Stefano et al. 2014). Gaining insights into this link - the microfoundation of DCs-is crucial because it provides options for influencing the application of dynamic capabilities (Felin et al. 2015).

Hence, we aim to explore the link between mechanisms on microlevel and DCs by answering the research question of how management affects the application of dynamic capabilities in NPOs active in refugee aid. A quantitative study among managers deployed in refugee camps all over Austria was conducted to answer this question. Based on the dynamic capability approach, we expect that NPOs coping successfully with the dynamics of refugee crisis applied dynamic capabilities and that managers' behavior affected their application.

Our paper makes the following contributions: Firstly, it provides evidence on how management and dynamic capabilities are linked, and thus adds to the highly claimed microfoundation of DCs in general (Sprafke et al. 2013; Teece 2007, 2014) and in the context of NPOs in particular. We examine the microfoundation of DCs in NPOs, where research regarding the microfoundation of DCs is even scarcer. Secondly, we provide an integrative illustration of management-related microfounding mechanisms and introduce participative leadership as a hardly researched leadership style potentially enhancing DCs. Thirdly, the illustration of microfounding managerial mechanisms provides opportunities for influencing or rather managing the application of DCs. This is particularly important because DCs enable continuous organizational change, which in turn supports NPOs to meet civil society's changing needs. Fourthly, referring to NPO practice, we point out how managers can govern DCs.

The remainder of this paper is structured as follows; we first discuss the nature of dynamic capabilities and elaborate what these DCs could look like in refugee aid. We then illustrate the microfoundation of DCs as our theoretical background and explain how management can orchestrate the application of DCs in refugee aid. In the third section, we present the empirical results of our survey using a mediation analysis. The final section contains a brief discussion. 


\section{Framing Dynamic Capabilities in Theory and Practice}

\section{Nature and Relevance of Dynamic Capabilities}

Despite difference in understandings of dynamic capabilities (Hsu and Wang 2010; Wang et al. 2015), there is consensus in the literature that the purpose of DCs is balancing the organization's, the employees' and the customers' needs as well as other 'business opportunities' (Baretto 2010; Eisenhardt and Martin 2000) in order to 'maintain leadership in continually shifting business environments' (Teece 2014, 329 f.). Scholars also agree that dynamic capabilities represent 'higher-level activities' (i.a. Teece 2014; Güttel and Konlechner 2009) or 'meta-capabilities' (Baretto 2010; Eisenhardt and Martin 2000) because they can govern other capabilities. DCs 'enable the firm to integrate, build, and reconfigure internal and external resources' (Teece 2014, 335). 'Higher-level activities' or 'meta-capabilities' also refer to the fact that DCs are not directly observable or visible. DCs become visible as soon as 'ordinary' capabilities ${ }^{3}$ and activities, such as knowledge or information processing, learning, coordination and reconfiguring activities 'operationalize' them. 'Dynamic' refers to how the resource base is changed (Ambrosini and Bowman 2009). A capability is dynamic, provided the velocity of capability (re-)configuration corresponds to the velocity of environmental dynamics (Teece 2007; Eisenhardt and Martin 2000).

DCs are relevant because they provide two 'added values' in relation to ordinary capabilities (Kaltenbrunner 2018). The first 'value added' of DCs is that DCs facilitate organizations' adaptation to changing environmental conditions repeatedly (Teece 2007, 2014) or systematically and over time (Hsu \& Wang 2010). This is what Teece (2014) defines as 'dynamic fit.' In the case of NPOs active during the refugee crisis, this fit consisted in 'translating' the needs of refugees into services such as providing food, setting up camps or lobbying as fast as needs were changing. The second 'added value' of DCs emanates from their potential to generate a 'multi-perspective fit', not only a 'strategic fit' in terms of Chandler (1962). This implies that DCs can cope with dilemmas ${ }^{4}$ in terms of multi-dimensional, partly conflicting interests, such as discrepant dominant logics of diverse internal and external stakeholders. During the refuge crisis, NPOs were, e.g., challenged to combine standard procedures of CEM disaster

\footnotetext{
${ }^{3}$ Ordinary capabilities involve the performance of administrative, operational, and governance-related functions that are (technically) necessary to accomplish tasks (Teece 2014, 328).

${ }^{4}$ Such dilemmas are particularly characteristic for NPOs, due to its association logic (Lichtsteiner et al. 2015; Meyer and Simsa 2013).
}

management (logic one) and activism, experimental search logics, such as intuition (logic two). By enhancing dynamic as well as multi-perspective fit, DCs support the organizational capacity to adapt and hence to compete in dynamic environments over time (Di Stefano et al. 2014, 315) and is reflected in strong evidence for a DC performance link (Teece et al. 1997, Teece 2007; Wang and Ahmed 2007).

\section{Conceptualization of Dynamic Capabilities and Refugee Aid}

Following Teece's et al. (1997, 2007, 2014) understanding, DCs consist of three clusters of higher-level activities. These are sensing, seizing and transforming activities. As previously mentioned, sensing refers to identifying, scanning and monitoring environmental changes-opportunities and threats-and defining possible resource actions. This includes, e.g., having a good observation and judgment ability, a profound understanding of the impact of internal and external environments, a sense for major opportunities and threats and a sound information management ( $\mathrm{Li}$ and Liu 2014). Transferred to refugee crisis, sensing could manifest in the ability to estimate the direction and quantity of arriving refugees and to provide status reports, to detect the refugees' needs and to anticipate their impact on infrastructure and resources. Seizing opportunities as the second cluster of activities mean choosing among possible resource actions and implementing the selected decision(s). Thus, seizing refers to the ability of absorbing and assimilating information in order to make (timely) client-oriented decisions, to design systems and structures and to mobilize the necessary resources for addressing the needs and opportunities for implementing decisions (Teece 2014; Li and Liu 2014; Jantunen et al. 2012). Seizing in the crisis situation could be found in defining appropriate decision-making and coordination structures; in activating and mobilizing (existent) (slack) resources, particularly volunteers and partners on a local level; and in delineating a kind of 'business model' in order to guarantee food supply and medical care. Thirdly, the transforming cluster encompasses the ability of aligning tangible and intangible resources to the environmental dynamics. This is mainly done by reconfiguring or recombining different resources (Teece 2014; Jantunen et al. 2012). There are various forms of reconfiguration, i. e., bundling existent resources and capabilities in new ways (Den Hertog et al. 2010). Resource bundling could become evident in the NPOs' ability to bundle their capabilities for setting up camps in a new way in order to build temporary homes. Reconfiguring also includes enriching existing resources and capabilities with new resources and capabilities. Transferred to the refugee crisis, this would be the NPOs' ability to enrich emergency supply of clients with 
new resources and capabilities for providing continuous care. Furthermore, it refers to replication of resources and capabilities in new organizational and market domains, e. g., NPOs active in (international) tracing services could stretch these capabilities in order to provide migration services.

\section{Theoretical Framework of Dynamic Capabilities}

As illustrated above, DCs-particularly in the notion of Teece $(2007,2014)$ - are based on resources or bundles of resources. These bundles of resources determine essentially, if an organization can compete over time or not. This view goes in line with the resource-based approach of Wernerfelt (1984), which correspondingly represents one dominant theoretical foundation of the dynamic capability approach $^{5}$ (Di Stefano et al. 2014). Complementarily a 'dynamic dimension' is added to enrich the dynamic capabilities approach because scholars regard bundles of resources as important, but not sufficient for gaining competitive advantage in dynamic environments. The 'dynamic dimension' refers to the organization's capability to adapt to environmental changes (Teece et al. 1997). This perspective roots in evolutionary economics (Nelson and Winter 1982). Evolutionary economics becomes particularly apparent in the dynamic capabilities approach via routines as fundament or building blocks of DCs. Thus, Teece (2016) regards the dynamic capabilities approach as 'capabilities enriched economic theory.'

While the understanding of routines and capabilities is relatively elaborated, there is a lack of research regarding the microfoundation, the microlevel origins of routines and capabilities (Felin et al. 2012, p. 1351). Microfoundation movement in the field of strategy and organization theory deals with the definition of underlying elements and mechanisms, which shape dynamic capabilities encompassing processes, activities, structures, rules as well as conditions of individual behavior, such as cognitions and affects and individual-level or group-level actions (cf. Teece 2007; Eisenhardt et al. 2010). Felin et al. (2012) cluster microfoundation of routines and capabilities into three categories, which are individuals, processes/

\footnotetext{
5 Based on bibliometric methods, Di Stefano et al. (2014) identified seven theoretical foundations of dynamic capabilities approach. These are the resource-based view (Wernerfelt, 1984), the knowledge-based view (Kogut and Zander 1992), behavioral theory (Cyert and March 1963), evolutionary economics (Nelson and Winter 1982), network theory (Granovetter 1992), transaction cost economics (Williamson 1975) and the positioning view (Porter 1980). In line with the two seminal dynamic capabilities, conceptualizations of Eisenhardt and Martin (2000) and Teece et al. (1997) two perspectives dominate. These are behavioral theory promoted by Eisenhardt and Martin (2000) and resourced-based view in combination with evolutionary economics endorsed by Teece and colleagues.
}

interactions and structure. The first category individuals as micromechanisms can be deconstructed in a cognitive and motivational dimension (Nelson and Winter 1982; Becker et al. 2005; Mäkelä et al. 2012). Eisenhardt et al. (2010) highlight the significance of managers, particularly their cognitions, for balancing efficiency and flexibility. Similarly, Zahra et al. (2006, p. 9) stress the key role of managers as decision-makers in applying dynamic capabilities. The second category, interactions and processes, relates to formal (e.g., procedures, rules) and informal forms of coordination (e.g., norms, experience) and illustrates how they shape routines and capabilities (Felin et al. 2012). Organizational routines as building blocks of capabilities are established with an increased level of interactions (Nelson and Winter 1982). Interaction-related micromechanisms serve two different roles. Firstly, they can illustrate how DCs are applied ('operationalized'), e.g., knowledge and information processes constituting sensing. ${ }^{6}$ Secondly, processes as micromechanisms can describe how to govern or orchestrate DCs (cf. Coleman, 1990). In contrast to his earlier work, also Teece (2014) attributes managers an important role as micro-origin of dynamic capabilities. He emphasizes the role of managers in asset orchestration and leadership.

\section{Microfoundation of Dynamic Capabilities in NPOs: Research Model and Hypotheses}

Even if DCs are scarcely discussed in nonprofit research, scholars provide evidence that DCs are appropriate for NPOs, too. Pablo et al. $(2007,691)$ state that DCs are 'providing synergistic benefits through internal processes irrespective of market structures, a condition that could apply to either private or public organizations'. Bryson et al. (2007) note that DCs particularly enable NPOs to meet their stakeholders' needs. Garrido and Camarero (2014) claim that NPOs' organizational existence-similar to FPO - depends on sustainable competitive advantages, which in turn are influenced by DCs.

However, there is hardly research, which provides evidence regarding the microfoundation of DCs in NPOs (Piening 2013; Kaltenbrunner 2018). As previously mentioned, micromechanisms can refer to individuals, processes and interactions as well as structures (Felin et al. 2012). Process-related micromechanisms can either illustrate how DCs are applied ('operationalized'), e.g., knowledge and information processes constituting sensing, ${ }^{7}$ or they

\footnotetext{
${ }^{6}$ See illustration of DCs constituting processes and activities in chapter 2 .

${ }^{7}$ Compare for the illustration of DCs constituting processes, activities in chapter 2 .
} 
describe how they orchestrate or govern DCs (cf., Coleman, 1990). In this context, Teece (2014) states that especially 'the role of individual action by [...] managers, the role of resources, strategy, and [...] have been omitted or poorly integrated into the dynamic capabilities literature (p. 328)'. Similarly, Di Stefano et al. (2014) mention that research still lacks empirical evidence regarding the linkage between leadership as microlevel phenomenon and dynamic capabilities as macro-level phenomena; the scholars recommend focusing on managerial cognitions.

In light of these observations, this paper seeks to explore how management affects the application of dynamic capabilities in NPOs active in refugee aid. As illustrated in Fig. 1, we assume that managerial behavior (participative leadership) and managerial characteristics (psychological empowerment) affect DCs. The illustration of microfounding managerial mechanisms is highly relevant because it provides opportunities for influencing and managing the application of DCs

\section{Participative Leadership and Dynamic Capabilities}

We consider participative leadership as joint decisionmaking process, or at a minimum as shared influence of a manager and his or her employees in decision-making (Somech 2006; Koopman and Wierdsma 1998). Participative leadership describes managerial behaviors that 'use attentive listening and careful observation of nonverbal cues of member needs, feelings, etc.; serve as a consultant, advisor, teacher, and facilitator, model, and encourage appropriate leader behaviors; establish a climate that is conducive to expression of both feelings and ideas; encourage the group to address its maintenance needs and process problems in its regular group meetings; and relinquish control, allowing the group to make final decisions on appropriate issues' (Yukl 1981, 246 f.).

We regard participative leadership as a pivotal informal coordination mechanism between the manager and his/her team substituting missing formal structures and coordination mechanisms in the context of refugee crisis.

In contrast to transactional and transformational leadership, there is hardly research dealing with the effects of participative leadership on dynamic capabilities; exceptions are i.a. Fillipini et al. (2012) or Saunila et al. (2014). Fillipini et al. (2012) provide evidence that i.a participative leadership promotes ambidextrous initiatives. Saunila et al. (2014) found that participative leadership, especially in small enterprises, has positive effects on dynamic capabilities in terms of innovation capability. Similarly, Leskovar-Spacapan and Bastic (2007) show that participative leadership promotes creativity, which in turn facilitates innovation.

Scholars state that participative leadership opens communication channels, enhances interactions and thus increases the flow and use of information and knowledge (Schreiber and Carley 2006, 69). Individuals can gather information relevant for fulfilling their tasks and turn their ideas and individual knowledge into innovative services, products or procedures (Somech 2006, 152). In other terms, participative leadership provides conditions like enhanced interactions, which can facilitate the evolvement of human capital, such as cognitions (e.g., expertise) as well as the evolvement of social capital (Schreiber and Carley 2006, 71). The enhanced human (and social) capital in turn can result in enhanced learning and adaptive outcomes (Schreiber and Carley 2006, 69, 72), which are strongly related to DCs. Increased levels of interactions enhance organizational routines which are essential building blocks of (dynamic) capabilities (Nelson and Winter 1982). We propose that participative leadership affects DCs via enhanced outcomes and increased levels.

$\mathbf{H}_{1(+)} \quad$ Participative leadership relates positively to dynamic capabilities.

\section{Psychological Empowerment and Dynamic Capabilities}

It is well established that individual cognitions affect the application of dynamic capabilities (Helfat and Peteraf 2015; Adner and Helfat 2003). Psychological empowerment represents a set of cognitions. Following Thomas and Velthouse (1990), Spreitzer (1995, 1443) defines psychological empowerment as 'intrinsic task motivation

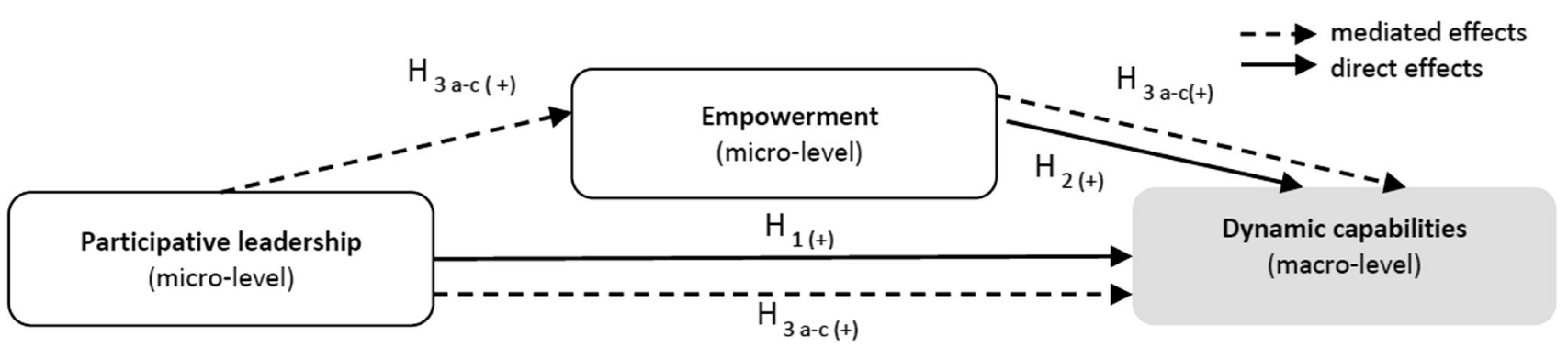

Fig. 1 Research model 
manifested in a set of four cognitions reflecting an individual to his or her work role'. Empowerment fosters individuals to launch initiatives and to handle uncertainty and risks (Spreitzer 1995). These effects are fundamental for coping with dynamic environments. Moreover, psychological empowerment relates positively to learning and innovation (Sears and Baba 2011) as well as to creativity (Deci et al. 1989). Learning, innovation and creativity are capabilities, which in turn are positively associated with dynamic capabilities. With regard to dynamic capabilities, Sprafke et al. (2013) provide evidence that psychological empowerment positively affects dynamic capabilities. This is due to the fact that psychological empowerment improves individual-level competences and perceived empowering working conditions enhance organizational capabilities. Psychological empowerment also increases self-efficacy of individual actors because highly competent individuals enjoy increased autonomy and self-determination and less competent individuals are provided with confidence in acting (Sprafke 2016). Phoocharoon (2011) provides evidence that psychological empowerment enhances the relationship between team learning behavior and the dynamic capability 'absorptive capacity'. Further, Hopkins et al. (2013) discuss the relationship between psychological empowerment, commitment and strategic renewal and prove that empowerment positively effects strategic renewal. Hence, we propose that managers active in refugee aid, who feel self-empowered foster the application of dynamic capabilities because they feel more competent to handle risks and uncertainties in refugee aid and they perceive the working conditions as appropriate to do their jobs. We therefore hypothesize that

$\mathbf{H}_{2(+)} \quad$ The manager's psychological empowerment is linked positively to dynamic capabilities.

\section{Participative Leadership, Psychological Empowerment and Dynamic Capabilities}

Following the discussion above, we propose that the direct relationship between participative leadership and dynamic capabilities is mediated by psychological empowerment, which is illustrated by the manager's perception of his competence, impact and self-determination. We assume that the participation and integration of team members in decision-making processes allow the manager to benefit from the team's knowledge, creativity, ideas in terms of expanding knowledge and acquiring new skills (Srivastava et al. 2006). This in turn enhances the manager's perceived empowerment, especially his/her self-efficacy and impact of his/her actions.

Thus, we assume a positive relationship between participative leadership, psychological empowerment and dynamic capabilities which results in the following hypotheses:

$\mathbf{H}_{3 \mathrm{a}(+)}$ The positive effect of participative leadership on DC is mediated by self-determination.

$\mathbf{H}_{3 \mathrm{~b}(+)}$ The positive effect of participative leadership on DC is mediated by the leader's self-perception of his/her impact.

$\mathbf{H}_{3 \mathrm{c}(+)}$ The positive effect of participative leadership on DC is mediated by the leader's self-perception of his/her competence.

Figure 1 illustrates our research model and the corresponding hypotheses.

\section{Research Design}

\section{Sample}

For gathering information on participative leadership, empowerment and dynamic capabilities during the refugee crisis in 2016 we used a survey instrument developed in close cooperation with a variety of experts. In a first step, interviews of two NPO managers plus two scientists in the fields of strategic management and human resource management, respectively, were conducted about the instrument itself and the most appropriate group of respondents for the information needed. In a second step, four NPO practitioners pretested the instrument resulting in small adaptions of the questionnaire. The experts consulted shared a strong opinion on people holding management functions as the only eligible respondents being able to assess dynamic capabilities. Also, this very dynamic situation differed significantly from a standard way of organizing that would allow for a clear and stable allocation of employees to managers. Instead, during the peak of the refugee crises the majority of people not holding management positions were volunteers with partly very short lived commitment leading to enormous turnover rates that made the subordinate level very hard to grasp. We thus approached people holding management positions via an online platform connecting NPOs active in refugee aid.

In total, 340 respondents started the survey of which 90 held management functions and could thus continue with the survey. Out of these 90, 16 showed more than 30\% 'missing values' (cf. Cohen et al. 2003) and were thus excluded. Our final sample consists of 74 managers active in refugee aid.

Table 1 describes the sample. In general, managers active in refugee aid were mostly male (79\%). On average, the managers were about 40 years old and more than twothird were married or live in a relationship. $45 \%$ of the 
Table 1 Respondent characteristics

\begin{tabular}{llll}
\hline Variables & & & \\
\hline Gender & $\%$ & Type of employee & $\%$ \\
Male & 79.0 & Voluntary leader & 45.5 \\
Female & 21.0 & Paid leader & 54.5 \\
Age & Absolute value & Intensity of activity & Absolute value \\
Mean (in years) & 39.7 & Hours per month & 38.9 \\
Marital status & $\%$ & Education & $\%$ \\
Single/divorced/widowed & 2.8 & University & 45.9 \\
Relationship/married & 66.1 & High school (with A level) & 32.8 \\
& & High school (without A.) & 21.3 \\
\hline
\end{tabular}

$N=74$

managers had a university degree. On average they spent $39 \mathrm{~h}$ per month in refugee aid. A little more than half of the respondents were paid staff $(55 \%)$. The managers were working or volunteering for two well-established Austrian NPOs active in civil aid and rescue services. Organization A was founded in 1880 and currently has about 8.200 paid employees plus 73.000 volunteers and 4.300 civil servants. Organization B was founded in 1938 and has 14.000 paid and 40.000 voluntary employees.

\section{Measures}

\section{Dependent Variables}

For measuring dynamic capabilities as dependent variable, we draw on the scale of Li and Liu (2014). We use this DC scale because in contrast to most other DC scales, it has already been used in a setting other than competitive market structures (e.g., no complete market conditions and much political influence) which best approximate the conditions of refugee crisis. Li and Liu (2014) define DCs as constructs of three dimensions. These are 'sense-making capacity' (six items, e.g., 'we can fully understand the impact of internal and external environments'; 'we have good observation and judgment abilities'), 'timely decision-making capacity' (four items, e.g., 'under many circumstances we can make timely decisions to deal with strategic problems'; 'we can quickly deal with conflicts in the strategic decision-making process') and 'change implementation capacity' (five items, e.g., 'our strategic changes can be carried out efficiently'; 'we help each other in strategic change implementation').

\section{Independent Variables}

For capturing the predictor variable participative leadership, we draw on the scale from Hoch et al. (2013). The scholars applied the scale in an innovation context, which is similar to a DC context. This scale encompasses four items (e.g., 'I decide, together with my team, which tasks have to be done'; 'my team and I sit down together and reach agreements on the tasks to do') measuring participative goal setting leadership.

Following previous DC research (cf. Sprafke et al., 2013), we chose psychological empowerment according to Spreitzer (1995) as mediator variable. This scale measures empowerment by drawing on four dimensions with three items each. These are 'competence' (e.g., 'I am confident about my ability to do my job'), 'self-determination' (e.g., 'I can decide on my own how to go about doing my job'), 'impact' (e.g., 'I have significant influence over what happens in my department') and 'meaning' (e.g., 'The work I do is meaningful'). Due to the fact that refugee crisis represents an emergency situation, where reflections about the meaning in terms of the 'fit between the needs of one's work role and one's beliefs, values and behavior' (Spreitzer 1995, 603) are hardly possible, we decided to exclude 'meaning' as empowerment dimension. The study includes 'environmental dynamics' and 'task complexity' as control variables, which might affect the relation between participative leadership and DCs, particularly because these variables are context dependent. We measured 'environmental dynamics' using the item 'our clients regularly ask for new products and services' suggested by Jansen et al. (2006). Following Gaitanides and Stock (2004), 'task complexity' was assessed through the item 'the tasks of our team mainly involve solving complex problems'.

\section{Factor Analysis, Reliability and Validity}

Due to the explorative character of DCs, we did a factor analysis of the DC scale as well as on empowerment. For DCs, the three factor structure proposed by $\mathrm{Li}$ and Liu (2014) could not be confirmed. The 'capacity for timely decision-making' did not show. Two of the items neither showed high enough loadings on the two factors identified 
nor formed their own factor. The remaining two items 'under many circumstances we can make timely decisions to deal with strategic problems' and 'We can remedy quickly to unsatisfactory customers' had high factor loadings on the other two dimensions. The factor 'change implementation' could be reproduced. KMO values for these two dimensions exceed the recommended value of 0.6 (Weiber and Mühlhaus 2014, 133; Backhaus et al. 2016, 398 f.). Reliability analysis produced Cronbach's $\alpha$ values ranging from .659 to .808 . Thus, scales are above the minimum level of 0.6 (Bagozzi and Yi 1988), which indicates internal consistency. The factor analysis of the items used for psychological empowerment neither showed the suggested three factor structure (Spreitzer, 1995). While the dimension 'competence' could be replicated 'impact' and 'self-determination' merged into one factor that we name 'impact_self-determination.' Again, KMO values of the scales exceed the recommended value of 0.6. Reliability analysis produced Cronbach's $\alpha$ values ranging from .838 to .877 . Finally, reliability analysis of the fouritem participative leadership scale confirms one factor with Cronbach's $\alpha=$.829. Also, AVE, examining validity, exceeds the cutoff value of 0.5 (Weiber and Mühlhaus 2014, 64).

\section{Findings}

In order to test for linear direct and mediated effects, we employed ordinary least square regression combined with bootstrapping. We tested for model assumptions using scatterplots, VIF and a Kolmogorov-Smirnov test for normal distribution and did not find hints pointing to multicollinearity, heteroscedasticity or nonnormal distribution.

Table 2 contains means, standard deviations and correlations between the variables used. DCs significantly correlate with participative leadership and with one dimension of psychological empowerment, i.e., 'impact_autonomy'. The relationship with the competence dimension is strong, but not significant $(p=.06)$. The control variable environmental dynamics are significantly associated with DCs, while task complexity does not show any effect. Participative leadership is significantly correlated with 'impact_autonomy', but not with 'competence' dimension of empowerment. Table 3 shows the results of the ordinary least square regression for the hypothesized direct effects. This includes the effects of participative leadership and psychological empowerment on dynamic capabilities (model 3) as well as their effects on the specific DC 'sensemaking' (model 1) and the DC 'change implementation capacity' (model 2). The illustration of these effects corresponds to $\mathrm{H}_{1}$ and $\mathrm{H}_{2}$.

The results in model 3 indicate that participative leadership has a significantly positive effect $\left(\beta=.355^{*}\right.$; $\mathrm{SE}=.137 ; p \leq .05)$ on dynamic capabilities, thus supporting $\mathrm{H}_{1}$. Differentiating between the two dimensions of empowerment identified in the factor analysis shows that 'impact_autonomy' is significant $(\beta=.211 *$; $\mathrm{SE}=.098$; $p \leq .05$ ), whereas the effect of the empowerment dimension 'competence' is nonsignificant $\left(\beta=.103^{*}\right.$; $\mathrm{SE}=.125$; $p=$ n.s.), thus finding only partial support for $\mathrm{H}_{2}$.

In order to substantiate the effects of participative leadership on dynamic capabilities, we added an analysis of the direct effects separating DCs into the two dimensions 'change implementation capacity' and 'sense-making capacity' identified in the factor analysis.

Model 2 illustrates the effects on the DC 'change implementation capacity'. The effect of participative leadership on this DC is positive and significant $\left(\beta=.369^{*} ; \mathrm{SE}=.161 ; p \leq .05\right)$, thus supporting $\mathrm{H}_{1}$. Further, the direct effect of the empowerment dimension 'impact_autonomy' on this DC is significant $\left(\beta=.268^{*}\right.$; $\mathrm{SE}=.115 ; p \leq .05)$, whereas the direct effect of the empowerment dimension 'competence' is nonsignificant
Table 2 Descriptive statistics and correlations

\begin{tabular}{|c|c|c|c|c|c|c|c|}
\hline \multicolumn{8}{|c|}{ Descriptive statistics and correlations } \\
\hline & Mean & SD & (1) & (2) & (3) & (4) & $(5)$ \\
\hline (1) Environmental dynamics & 1.027 & .162 & 1 & .098 & .116 & -.111 & .198 \\
\hline (2) Task complexity & .725 & .450 & .098 & 1 & $-.269 *$ & -.130 & .001 \\
\hline (3) Impact_autonomy & 2.320 & 1.100 & .116 & $-.269 *$ & 1 & $.335 * *$ & $.330 * *$ \\
\hline (4) Competence & 1.697 & .797 & -.111 & -.130 & $.335^{* *}$ & 1 & .179 \\
\hline (5) Participative leadership & 2.250 & .753 & .198 & .001 & $.330 * *$ & .179 & 1 \\
\hline (6) Dynamic capabilities & 3.029 & .912 & $.276^{*}$ & -.076 & $.417 * *$ & .215 & $.442 * *$ \\
\hline
\end{tabular}


Table 3 Results of regression analysis for direct effects

\begin{tabular}{|c|c|c|c|c|c|c|}
\hline \multirow[b]{3}{*}{ Intercepts } & \multicolumn{6}{|c|}{ Dynamic capabilities } \\
\hline & \multicolumn{2}{|c|}{ Model 1 sense-making } & \multicolumn{2}{|c|}{ Model 2 implementation } & \multicolumn{2}{|c|}{ Model 3 DCs (combined) } \\
\hline & -.025 & $(.846)$ & 1313 & $(.951)$ & .450 & $(.673)$ \\
\hline \multicolumn{7}{|l|}{ Independent variables } \\
\hline Task complexity & -.204 & $(.447)$ & -.272 & $(.502)$ & -.058 & $(.225)$ \\
\hline Environmental dynamism & $1.848 * *$ & $(.625)$ & .361 & $(.703)$ & 1.144 & $(.593)$ \\
\hline Participative leadership & $.345^{*}$ & $(.143)$ & $.369 *$ & $(.161)$ & $.355^{*}$ & $(.137)$ \\
\hline Competence & .098 & $(.132)$ & .112 & $(.148)$ & .103 & $(.125)$ \\
\hline Impact_autonomy & .190 & $(.102)$ & $.268^{*}$ & $(115)$ & $.211^{*}$ & $(.098)$ \\
\hline $\mathrm{R}^{2}$ & .316 & & .241 & & .308 & \\
\hline $\mathrm{F}$ & $6.286^{* * *}$ & & $4.322 * *$ & & $6.064 * * *$ & \\
\hline $\mathrm{N}$ & 74 & & 74 & & 74 & \\
\hline
\end{tabular}

OLS with robust standard errors; unstandardized coefficients and standard errors (in parentheses), ${ }^{*} p<.05 ; * * p<.01 ; * * * p<.001$

$(\beta=.112 ; \mathrm{SE}=.148 ; p=$ n.s. $)$, again finding only partial support for $\mathrm{H}_{2}$.

Model 1 shows the effects on the DC 'sense-making capacity'. Again, participative leadership affects this DC positively and significantly $\left(\beta=.345^{*} ; \mathrm{SE}=.143\right.$; $p \leq .05)$, thus supporting $\mathrm{H}_{1}$. The effects of both empowerment dimensions on this DC, though, are nonsignificant; 'impact_autonomy' shows $\beta=.190$; $\mathrm{SE}=.102 ; p=$ n.s and 'competence' shows $\beta=.098$; $\mathrm{SE}=.132 ; p=$ n.s. With regard to the DC 'sensemaking capacity', we have to reject $\mathrm{H}_{2}$.

In sum, models $1-3$ consistently support $\mathrm{H}_{1}$. Concerning the effects of psychological empowerment, the findings vary depending on which dimension of psychological empowerment and which DC is analyzed. Thus, the reported direct effects of empowerment are less appropriate for interpretation.

In order to test mediated effects as proposed by $\mathrm{H}_{3}$, we started with the procedure described by Baron and Kenny (1986). This stepwise path procedure starts with a regression of the dependent variable (Y), dynamic capabilities, on the independent variable $(\mathrm{X})$, participative leadership [c-path]. To continue mediation, the independent variable has to affect the dependent variable significantly. In a next step, the mediators (M), dimensions of psychological empowerment, are regressed on the independent variable, participative leadership [a-path]. Again, the relationships should be significant. Third, we deployed a regression of the dependent variable, DCs, on both: on participative leadership as independent variable [c-path] and on the dimensions of psychological empowerment as mediators [b-bath]. Here the mediators' effects on the dependent variable should be significant, while the independent variable should not be affected (nonsignificance for full mediation, less significance than in c-path for partial mediation).

Table 4 shows the mediated effects of the independent variable participative leadership via the proposed mediators 'impact_autonomy' $\left(\mathrm{H}_{3 \mathrm{ab}}\right)^{8}$ and 'competence' $\left(\mathrm{H}_{3 \mathrm{c}}\right)$ on dynamic capabilities as dependent variable.

- In the a-path, participative leadership influences 'impact_autonomy' significantly $(\beta=.517 * * ; \mathrm{SE}=.161$; $p \leq .01)$, but doesn't influence 'competence' $(\beta=.138$; $\mathrm{SE}=.132 ; p=$ n.s.). Hence, the empowerment dimension 'competence' does not meet the requirements for continuing mediation analysis.

- The b-path for 'impact_autonomy' on DCs is also significant $(\beta=.211 * ; \mathrm{SE}=.098 ; p \leq .05)$, but again not for 'competence' $(\beta=.103 ; \mathrm{SE}=.125 ; p=$ n.s. $)$.

- The total effect of participative leadership (c-path) is significant $(\beta=.489 * * ; \mathrm{SE}=.131 ; p \leq .01)$ and so is the c-path $\left(\beta=.355^{*} ; \mathrm{SE}=.137 ; p \leq .05\right)$.

Accordingly, based on a positive and significant a-path and b-path, findings imply partial mediation for participative leadership through 'impact_autonomy'; this supports $\mathrm{H}_{3 \mathrm{ab}}$. Due to the lack of significance in a-path and b-path, $\mathrm{H}_{3 c}$ is rejected.

As Table 5 shows, the bootstrapped results support these findings because the confidence intervals for 'impact_autonomy' is above zero (.0170 to .2746), whereas the

\footnotetext{
${ }^{8}$ As mentioned in chapter 4.2 due to results of factor analysis composition of scales changed. This in turn modified the design of proposed hypotheses. Due to the fact that 'impact' and 'selfdetermination' do not represent separate scales, but one, hypotheses $\mathrm{H}_{3 \mathrm{a}}$ und $\mathrm{H}_{3 \mathrm{~b}}$ are merged into $\mathrm{H}_{3 \mathrm{ab}}$.
} 
Table 4 Results of regression analysis for the mediated effects on dynamic capabilities

\begin{tabular}{|c|c|c|c|c|c|c|c|c|}
\hline \multirow[b]{2}{*}{ Intercepts } & \multicolumn{2}{|c|}{ Impact_autonomy (a-path) } & \multicolumn{2}{|c|}{ Competence (a-path) } & \multicolumn{2}{|c|}{ DCs (c-path) } & \multicolumn{2}{|c|}{ DCs (b- \& c-paths) } \\
\hline & 1.222 & $(.788)$ & 1.838 & $(.612)$ & .921 & $(.642)$ & .450 & $(.673)$ \\
\hline \multicolumn{9}{|l|}{ Independent variables } \\
\hline Task complexity & $-.791 * *$ & $(.268)$ & -.0964 & $(.217)$ & -.251 & $(.219)$ & -.058 & .225 \\
\hline Environmental dynamism & .5264 & $(.737)$ & -.818 & $(.565)$ & 1.182 & $(.601)$ & 1.144 & $(.593)$ \\
\hline Participative leadership & $.517 * *$ & $(.161)$ & .138 & $(.132)$ & $.489 * *$ & $(.131)$ & $.355^{*}$ & $(.137)$ \\
\hline \multicolumn{9}{|l|}{ Mediators } \\
\hline Impact_autonomy & & & $.203^{*}$ & $(.091)$ & & & $.211 *$ & $(.098)$ \\
\hline Competence & & & & & & & .103 & $(.125)$ \\
\hline$R^{2}$ & .222 & & .142 & & .240 & & .308 & \\
\hline$F$ & $6.660 * * *$ & & $2.858^{*}$ & & $7.380 * *$ & & $6.064 * * *$ & \\
\hline$N$ & 74 & & 74 & & 74 & & 74 & \\
\hline
\end{tabular}

OLS with robust standard errors; unstandardized coefficients and standard errors (in parentheses), * $p<.05 ; * * p<.01 ; * * * p<.001$

Table 5 Bootstrapped results for the indirect effects of participative leadership on dynamic capabilities

\begin{tabular}{lcccc}
\hline Mediators & Effect & Boot SE & Boot LLCI & Boot ULCI \\
\hline Total & .1339 & .0680 & .0339 & .3228 \\
Indicator 1 & .2089 & .0605 & .0170 & .2746 \\
Indicator 2 & .0108 & .0164 & -.0059 & .0755 \\
Indicator 3 & .0160 & .0404 & -.0158 & .1799
\end{tabular}

Ind1: SKF_PART $\rightarrow$ SKF_Auto $\rightarrow$ SKF_DC

Ind2: SKF_PART $\rightarrow$ SKF_Auto $\rightarrow$ SKF_Comp $\rightarrow$ SKF_DC

Ind3: SKF_PART $\rightarrow$ SKF_Comp $\rightarrow$ SKF_DC

intervals for 'competence' include zero ( -.0158 to .1799); similarly, the simultaneous mediation of both psychological empowerment dimensions also includes zero (- .0059 to.0755).

\section{Discussion and Conclusions}

The Refugee crisis of 2016 with its ambiguous, multi-dimensional and dynamically changing environmental conditions made evident that dynamic capabilities represent a crucial asset for NPOs because they facilitated NPOs to achieve the required continuous organization-environment fit. In other terms, DCs enabled NPOs to meet continuously changing civil society's needs. In the case of NPOs active in refugee aid, this fit consisted in translating the needs of refugees into services, such as providing food, setting up camps or lobbying as fast as needs were changing. Dynamic capabilities are said to accomplish such a fit due to their property as meta-capabilities and thus governing other capabilities systematically and over time (Hsu and Wang 2010; Teece 2014).
In order to better understand the nature of DCs and particularly to provide options for influencing the application of dynamic capabilities in refugee aid, we aim to explore mechanisms on microlevel, which found DCs. This is what research defines as microfoundation of DCs (Teece 2007; Felin et al. 2015). Following Di Stefano et al. (2014) and Teece (2014), research particularly lacks of an integrated consideration of management-related aspects, e.g., managerial behavior and cognitions. Hence, we analyzed the link between micromechanisms and DCs on macrolevel by examining how management affects the application of dynamic capabilities in NPOs. In this context, we include managerial behavior-by drawing on participative leadership-as well as managerial characteristics-by integrating psychological empowerment-into our research model.

Concerning the relationship between participative leadership and dynamic capabilities, we assume that participative leadership positively influences managers' application of dynamic capabilities. This is because team members' knowledge, ideas, and creativity-gained through participative leadership-are enablers for DCs. We provide evidence for direct effects between participative leadership and dynamic capabilities, illustrated via $\mathrm{H}_{1}$. This is in line with previous research in the field of dynamic capabilities (cf. Saunila et al. 2014; Filippini et al. 2012) as well as with strategic management research in general (cf. LeskovarSpacapan and Bastic 2007; Gottschalg and Zollo 2007; Lindenberg and Foss 2011).

We suppose that NPOs active in refugee aid (or under comparable ambiguous, dynamically changing and multidimensional emergency situations) use participative leadership in terms of interactive decision patterns as substitute for nonexisting organizational structures, respectively, 
Table 6 Overview of hypotheses support

\begin{tabular}{ll}
\hline & Hypotheses \\
\hline Direct effects & Predictor and outcome variables \\
$\mathrm{H}_{1(+)}$ & $\begin{array}{l}\text { Participative leadership relates positively to DCs } \\
\text { Mediators and outcome variables }\end{array}$ \\
$\mathrm{H}_{2(+)}$ & Manager's psychological empowerment is linked positively to DCs \\
$\begin{array}{l}\text { Mediated } \\
\text { effects }\end{array}$ & Predictor, mediator and outcome variables \\
$\mathrm{H}_{3 \mathrm{ab}(+)}$ & The positive effect of participative leadership on DCs is mediated by the manager's self-perception of his/her \\
& impact_self-determination \\
$\mathrm{H}_{3 \mathrm{c}(+)}$ & The positive effect of participative leadership on DCs is mediated by the manager's self-perception of his/her \\
& competence
\end{tabular}

$\checkmark$ Hypotheses supported-, $\times$ hypotheses not supported; $\sim$ partly supported

coordinative mechanisms. For instance, participative leadership can serve as substitutive for routines, e.g., standard operation procedures, which do not or rather only partly exist in such emergency situations. In this context, participative leadership is comparable to task forces or staff work.

Further, we deployed a differentiated analysis and explored the effects of participative leadership on the DC dimensions 'sense-making capacity' and 'change implementation capacity' separately. Whereas the findings indicate a significant and positive effect regarding 'change implementation capacity', it was nonsignificant concerning 'sense-making capacity'. This could be due to the fact that team members can only restrictively serve as 'sense-makers' because they are not primarily cognizant of the overall political, economic or humanitarian situation and its dependences; they are experts, though, in delivering services which makes team members predestinated to provide information regarding 'changes in implementation'.

In order to explore managerial influence on dynamic capabilities profoundly, we also explored the effect of psychological empowerment. Findings show that the empowerment dimension 'impact_self-determination' affects dynamic capabilities significantly. Thus, the managers' perceptions, how self-determined (s)he is and how impactful his/her actions are, foster dynamic capabilities. This is because managers perceiving such cognitions are more motivated to take initiatives, to innovate as well as to increase performance (Sprafke et al. 2013). Psychological empowerment shows that cognitions are strongly linked with motivation; Spreitzer (1995) actually defines psychological empowerment as intrinsic task motivation. It is particularly important for NPOs to consider psychological empowerment in their capacity building because mainly intrinsic motivated volunteers constitute their work force. The effect of the second dimension 'competence' was not significant, though.
Our research focus was to explore the linkage between participative leadership, psychological empowerment and dynamic capabilities. In this relationship, psychological empowerment is considered to mediate the effects of participative leadership on dynamic capabilities. Comparable to findings mentioned above, we could not find evidence for the effect of 'competence' $\left(\mathrm{H}_{3 \mathrm{c}}(+)\right)$ on DCs, but for the effect of 'impact_self-determination', supporting $\mathrm{H}_{3 \mathrm{ab}}$. 'Impact_self-determination' mediates participative leadership partially. This implies that this empowerment dimension enhances the effect of participative leadership on DCs.

Table 6 provides an overview regarding the tested hypotheses.

Finally, we also provide evidence that DCs have a highly significant effect on organizational performance (cf. Table 2). Applying DCs increases NPOs performance in refugee aid or rather supports them to positively impact civil society's needs.

The profound empirical evidence provided by our paper contributes significantly to the understanding of interdependences of DCs, management behavior and managerial cognitions. We examine this microfoundation in NPOs, where DC research is even more underrepresented. Hence, our study enlarges the research context of DCs. We found that managers represent a meaningful agent of DCs on microlevel and thus contribute to the behavioral foundation of organizations, which is an essential research stream of microfoundation to further explore (Felin et al. 2015). By analyzing managerial behavior (participative leadership) as well as managerial cognitions (psychological empowerment), we even provide an integrative illustration of management-related microfounding mechanisms. In contrast to previous research, which particularly focused on transactional and transformational leadership, we introduced and empirically proved participative leadership as a 'new' DC enhancing leadership style. Our study shows that 
participative leadership represents a crucial, foremost informal coordination mechanism that can serve as substitute for barely existing formal coordination mechanisms in highly dynamic and even crisis situations. We show strong associations between participative leadership and DC, mediated by psychological empowerment. This suggests that actively stimulating a certain leadership style can have an impact on DCs and thus on organizational survival.

Acknowledgements Open access funding provided by Paris Lodron University of Salzburg.

\section{Compliance with Ethical Standards}

Conflict of interest The authors declare that they have no conflict of interest.

Open Access This article is distributed under the terms of the Creative Commons Attribution 4.0 International License (http://creative commons.org/licenses/by/4.0/), which permits unrestricted use, distribution, and reproduction in any medium, provided you give appropriate credit to the original author(s) and the source, provide a link to the Creative Commons license, and indicate if changes were made.

\section{References}

Adner, R., \& Helfat, C. (2003). Corporate effects and dynamic managerial capabilities. Strategic Management Journal, 24(10), 997-1010.

Ambrosini, V., \& Bowman, C. (2009). What are dynamic capabilities and are they a useful construct in strategic management? International Journal of Management Reviews, 11(1), 29-49.

Anheier, H. K. (2005). Nonprofit organizations. Theory, management and policy. London: Routledge.

Backhaus, K., Erichson, B., Weiber, R., \& Plinke, W. (2016). Multivariate analysemethoden. Berlin: Springer.

Bagozzi, R. P., \& Yi, Y. (1988). On the evaluation of structural equation models. Journal of the Academy of Marketing Science, 16(1), 74-94.

Baron, R. M., \& Kenny, D. A. (1986). The moderator-mediator variable distinction in social psychological research: Conceptual, strategic, and statistical considerations. Journal of Personality and Social Psychology, 51(6), 1173-1182.

Barreto, I. (2010). Dynamic capabilities: A review of past research and an agenda for the future. Journal of Management, 36(1), 256-280.

Becker, M. C., Lazaric, N., Nelson, R. R., \& Winter, S. G. (2005). Applying organizational routines in understanding organizational change. Industrial and Corporate Change, 14(5), 775-791.

Bryson, J. M., Ackermann, F., \& Eden, C. (2007). Putting the resource-based view of strategy and distinctive competencies to work in public organizations. Public Administration Review, 67 (4), 702-717.

Bundesministerium für Inneres. (2017). Vorläufige Asylstatistik 2015. http://www.bmi.gv.at/cms/BMI_Asylwesen/statistik/files/Asyl statistik_Dezember_2015.pdf. 05 April 2017.

Bundesministerium für Inneres. (2017). Vorläufige Asylstatistik 2016. http://www.bmi.gv.at/301/Statistiken/files/2016/Asylstatistik_ Dezember_2016.pdf. 05 April 2017

Chandler, A. D. (1962). Strategy and structure: Chapters in the history of the American industrial enterprise. Cambridge, MA: MIT Press.
Cohen, J., Cohen, P., West, S. G., \& Aiken, L. S. (2003). Applied multiple regression/correlation analysis for the behavioral sciences. Mahwah, NJ: Lawrence Erlbaum Associates.

Coleman, J. (1990). Foundations of social theory. Boston, MA: Harvard University Press.

Cyert, R. M., \& March, J. G. (1963). A behavioral theory of the firm. Englewood Cliffs, NJ: Prentice-Hall.

Deci, E. L., Connell, J. P., \& Ryan, R. M. (1989). Self-determination in a work organization. Journal of Applied Psychology, 74(4), 580-590.

Den Hertog, P., van der Aa, W., \& de Jong, M. W. (2010). Capabilities for managing service innovation: Towards a conceptual framework. Journal of Service Management, 21(4), 490-514.

Di Stefano, G., Peteraf, M., \& Verona, G. (2014). The organizational drivetrain: A road to integration of dynamic capabilities research. The Academy of Management Perspectives, 28(4), 307-327.

Die Presse. (2016). Flüchtlinge: Österreich erlebte 2016 ein forderndes Jahr. http://diepresse.com/home/ausland/eu/5140352/Fluech tlinge_Oesterreich-erlebte-2016-ein-forderndes-Jahr. 05 April 2017.

Dynes, R. R. (1993). Disaster reduction: The importance of adequate assumptions about social organization. Sociological Spectrum, 13(1), 175-192.

Eisenhardt, K. M., Furr, N. R., \& Bingham, C. B. (2010), CROSSROADS-Microfoundations of performance: Balancing efficiency and flexibility in dynamic environments. Organization Science, 21(6), 1263-1273.

Eisenhardt, K. M., \& Martin, J. A. (2000). Dynamic capabilities: What are they? Strategic Management Journal, 21(10-11), $1105-1121$.

Felin, T., Foss, N. J., Heimeriks, K. H., \& Madsen, T. L. (2012) Microfoundations of routines and capabilities: Individuals, processes, and structure. Journal of Management Studies, 49 (8), 1351-1374

Felin, T., Foss, N. J., \& Ployhart, R. E. (2015). The microfoundations movement in strategy and organization theory. The Academy of Management Annals, 9(1), 575-632.

Filippini, R., Güttel, W. H., \& Nosella, A. (2012). Ambidexterity and the evolution of knowledge management initiatives. Journal of Business Research, 65(3), 317-324.

Frühwirth, R., \& Lachmayer, K. (2015). Privatisierung der Flüchtlingsbetreuung. Zwischen unternehmerischer Gewinnmaximierung und Zivilgesellschaft., 2015(4), 70-74.

Gaitanides, M., \& Stock, R. (2004). Interorganisationale Teams: Transaktionskostentheoretische Überlegungen und empirische Befunde zum Teamerfolg. Schmalenbachs Zeitschrift für betriebswirtschaftliche Forschung, 56(5), 436-451.

Garrido, M. J., \& Camarero, C. (2014). Learning and relationship orientation: An empirical examination in European museums. International Journal of Nonprofit and Voluntary Sector Marketing, 19(2), 92-109.

Gottschalg, O., \& Zollo, M. (2007). Interest alignment and competitive advantage. Academy of Management Review, 32(2), 418-437.

Granovetter, M. (1992). Problems of explanation in economic sociology. In N. Nohria \& R. Eccles (Eds.), Networks and organizations: Structure, form and action (pp. 25-56). Boston, MA: Harvard Business School Press.

Gratz, W. (2016). Das Management der Flüchtlingskrise. Never let a good crises go to waste.Wien/Graz: Neuer Wissenschaftlicher Verlag.

Güttel, W. H., \& Konlechner, S. W. (2009). Continuously hanging by a thread: Managing contextually ambidextrous organizations. Schmalenbach Business Review, 61(2), 150-171. 
Helfat, C. E., \& Peteraf, M. S. (2015). Managerial cognitive capabilities and the microfoundations of dynamic capabilities. Strategic Management Journal, 36(6), 831-850.

Hoch, J. E. (2013). Shared leadership and innovation: The role of vertical leadership and employee integrity. Journal of Business and Psychology, 28(2), 159-174.

Hopkins, W. E., Mallette, P., \& Hopkins, S. A. (2013). Proposed factors influencing strategic inertia/strategic renewal in organizations. Academy of Strategic Management Journal, 12(2), 7794.

Hsu, L. C., \& Wang, C. H. (2010). Clarifying the effect of intellectual capital on performance: The mediating role of dynamic capability. British Journal of Management, 23(2), 179-205.

Jansen, J. J., Van den Bosch, F. A., \& Volberda, H. W. (2006). Exploratory innovation, exploitative innovation, and performance: Effects of organizational antecedents and environmental moderators. Management Science, 52(11), 1661-1674.

Jantunen, A., Ellonen, H. K., \& Johansson, A. (2012). Beyond appearances-Do dynamic capabilities of innovative firms actually differ? European Management Journal, 30(2), 141-155.

Kaltenbrunner, K. A. (2018). Dynamisierung des Nonprofit-Managements. Ein führungsorientierter Bezugsrahmen zur Mikrofundierung von Dynamic Capabilities in der Dienstleistungserstellung großer fremdleistungsorientierter Nonprofit-Organisationen. Wiesbaden: Springer.

Kogut, B., \& Zander, U. (1992). Knowledge of the enterprise, combinative capabilities and the replication of technology. Organizational Science, 3(3), 383-397.

Koopman, P. L., \& Wierdsma, A. F. M. (1998). Participative management. In P. J. D. Doentu, H. Thierry, \& C. J. de-Wolf (Eds.), Personnel psychology: Handbook of work and organizational psychology (vol. 3, pp. 297-324). Hove, UK: Psychology Press.

Leskovar-Spacapan, G., \& Bastic, M. (2007). Differences in organizations' innovation capability in transition economy: Internal aspect of the organizations' strategic orientation. Technovation, 27(9), 533-546.

Li, D. Y., \& Liu, J. (2014). Dynamic capabilities, environmental dynamism, and competitive advantage: Evidence from China. Journal of Business Research, 67(1), 2793-2799.

Lichtsteiner, H., Gmür, M., Giroud, C., \& Schauer, R. (2015). Das Freiburger Management-Modell für Nonprofit- Organisationen (8th ed.). Bern: Haupt.

Lindenberg, S., \& Foss, N. (2011). Managing joint motivation: The role of goal framing and governance mechanisms. Academy of Management Review, 36(3), 500-525.

Maduz, L. \& Roth, F. (2017). Lehren aus der Flüchtlingskrise 2015/2016: Ergebnisse des DA-CH Expertenworkshops (No. 8). ETH Zurich.

Maier, F., \& Ortner, J. (2017). Willkommen in Österreich. Was wir für Flüchtlinge leisten können und wo Österreich versagt hat. Innsbruck/Wien: Tyrolia.

Mäkelä, K., Sumelius, J., Höglund, M., \& Ahlvik, C. (2012). Determinants of strategic HR capabilities in MNC subsidiaries. Journal of Management Studies, 49(8), 1459-1483.

Meyer, M., Neumayr, M., \& Schneider, U. (2010). Bits and pieces: Daten zum österreichischen Nonprofit-Sektor. Fachzeitschrift für Verbands- und Nonprofit-Management, 36(2), 34-47.

Meyer, M., \& Simsa, R. (2013). NPOs: Abgrenzungen, Definitionen, Forschungszugänge. In R. Simsa, M. Meyer \& C. Badelt (Hrsg.), Handbuch der Nonprofit-Organisationen (pp. 1-14). Stuttgart: Schäffer-Pöschel.

Nelson, R., \& Winter, S. G. (1982). An evolutionary theory of economic change. Cambridge: Harvard Business School Presse.

Pablo, A. L., Reay, T., Dewald, J. R., \& Casebeer, A. L. (2007). Identifying, enabling and managing dynamic capabilities in the public sector. Journal of Management Studies, 44(5), 687-708.
Pavlou, P. A., \& El Sawy, O. A. (2011). Understanding the elusive black box of dynamic capabilities. Decision Sciences, 42(1), 239-273.

Phoocharoon, P. (2011). Architecture engagement dynamic: Contemporary approach to enhance employee creativity. International Journal of Innovation, Management and Technology, 2(4), 335.

Piening, E. P. (2013). Dynamic capabilities in public organizations: A literature review and re-search agenda. Public Management Review, 15(2), 209-245.

Porter, M. E. (1980). Competitive strategy: Techniques for analyzing industries and competition. New York: Free Press.

Roth, F. (2017). Herausforderungen und langfristige Implikationen der Flüchtlingskrise 2015/2016. Bericht zum D-A-CH Expertenworkshop (No.8). ETH Zürich.

Saunila, M., Pekkola, S., \& Ukko, J. (2014). The relationship between innovation capability and performance: The moderating effect of measurement. International Journal of Productivity and Performance Management, 63(2), 234-249.

Schreiber, C., \& Carley, K. M. (2006). Leadership style as an enabler of organizational complex functioning. Emergence: Complexity and Organization, 8(4), 2.

Sears, G. J., \& Baba, V. V. (2011). Toward a multistage, multilevel theory of innovation. Canadian Journal of Administrative Sciences/Revue Canadienne des Sciences de l'Administration, 28(4), 357-372.

Simsa, R. (2017). Leaving emergency management in the refugee crisis to civil society? The Case of Austria. Journal of Applied Security Research, 12(1), 78-95.

Simsa, R., \& Zimmer, A. (2014). Quo vadis? In A. Zimmer \& R. Simsa (Eds.), Forschung zu Zivilgesellschaft, NPOs und Engagement: Quo vadis? (pp. 11-37). Wiesbaden: Springer.

Somech, A. (2006). The effects of leadership style and team process on performance and innovation in functionally heterogeneous teams. Journal of Management, 32(1), 132-157.

Sprafke, N. (2016). Kompetente Mitarbeiter und wandlungsfähige Organisationen: Zum Zusammenhang von Dynamic Capabilities, individueller Kompetenz und Empowerment. Wiesbaden: Springer.

Sprafke, N., Wilkens, U., Schiffer, B., \& Feldmann, L. (2013). Bundles of micro-variables for describing organizational dynamic capabilities-commonalities and idiosyncrasies. In Paper presented at the 8th SKM Symposium jointly held with the 2nd Conference on Competence-based Strategic Management, Magdeburg.

Spreitzer, G. M. (1995). Psychological empowerment in the workplace: Dimensions, measurement, and validation. Academy of Management Journal, 38(5), 1442-1465.

Srivastava, A., Bartol, K. M., \& Locke, E. A. (2006). Empowering leadership in management teams: Effects on knowledge sharing, efficacy, and performance. Academy of Management Journal, 49(6), 1239-1251.

Teece, D. J. (2007). Explicating dynamic capabilities: The nature and microfoundations of (sustainable) enterprise performance. Strategic Management Journal, 28(13), 1319-1350.

Teece, D. J. (2014). The foundations of enterprise performance: Dynamic and ordinary capabilities in an (economic) theory of firms. The Academy of Management Perspectives, 28(4), 328-352.

Teece, D. J. (2016). Dynamic capabilities and entrepreneurial management in large organizations: Toward a theory of the (entrepreneurial) firm. European Economic Review, 86(C), 202-216.

Teece, D. J., Pisano, G., \& Shuen, A. (1997). Dynamic capabilities and strategic management. Strategic Management Journal, 18 (7), 509-533.

Thomas, K. W., \& Velthouse, B. A. (1990). Cognitive elements of empowerment: An "interpretive" model of intrinsic task motivation. Academy of Management Review, 15(4), 666-681. 
Wang, C. L., \& Ahmed, P. K. (2007). Dynamic capabilities: A review and research agenda. International Journal of Management Reviews, 9(1), 31-51.

Wang, C. L., Senaratne, C., \& Rafiq, M. (2015). Success traps, dynamic capabilities and firm performance. British Journal of Management, 26(1), 26-44.

Weiber, R., \& Mühlhaus, D. (2014). Strukturgleichungsmodellierung. Berlin/Heidelberg: Springer.
Wernerfelt, B. (1984). A resource-based view of the firm. Strategic Management Journal, 5(2), 171-180.

Williamson, O. E. (1975). Markets and hierarchies, analysis and antitrust implications. New York, NY: Free Press.

Yukl, G. A. (1981). Leadership in organizations. New York: Prentice Hall.

Zahra, S. A., Sapienza, H. J., \& Davidsson, P. (2006). Entrepreneurship and dynamic capabilities: A review, model and research agenda. Journal of Management Studies, 43(4), 917-955. 